\title{
Reading Comprehension and Self-Perceived School Performance in Elementary School
}

\author{
Andrea Carvalho Beluce ${ }^{1}$ \\ Amanda Lays Monteiro Inácio ${ }^{2}$ \\ Katya Luciane de Oliveira ${ }^{1}$ \\ Sandra Aparecida Pires Franco ${ }^{1}$ \\ ${ }^{1}$ Universidade Estadual de Londrina, Londrina, PR \\ ${ }^{2}$ Universidade São Francisco, Campinas, SP
}

\begin{abstract}
Abstratct
This research aimed to investigate the reading comprehension and possible associations with self-perception of academic performance in elementary and middle school students. The study included 298 students enrolled from the $2^{\text {nd }}$ to $9^{\text {th }}$ grades in public schools the states of São Paulo and Parana. Two Cloze tests were collectively applied: one specific for elementary school (first stage of basic education) and another for the middle school (second stage). Results indicated that the students presented an instructional reading comprehension. It was also possible to observe statistically significant differences between Cloze score and self-perception of academic performance. In general, it can be stated that the students who presented better levels of reading comprehension are also the ones that better self-assessed. The data are discussed considering the psychoeducational implications concerning the mode of education investigated.

Keywords: elementary school; Cloze test; academic performance; reading comprehension
\end{abstract}

\section{Compreensão de Leitura e Desempenho Escolar Autopercebido no Ensino Fundamental}

\section{Resumo}

Esta pesquisa teve por objetivo investigar a compreensão em leitura e possíveis associações com o desempenho escolar autopercebido em alunos do ensino fundamental. Participaram 298 estudantes matriculados do $2^{\circ}$ ao $9^{\circ}$ anos em escolas públicas dos Estados de São Paulo e Paraná. Foram aplicados, coletivamente, dois testes de Cloze: um específico para a primeira etapa do ensino fundamental e outro para a segunda. Os resultados demonstram que os alunos apresentaram uma compreensão em leitura considerada como instrucional. Foi possível também observar diferenças estatisticamente significantes entre a pontuação no Cloze e a autopercepção do desempenho escolar. No geral, pode-se dizer que os alunos que apresentaram melhor nível de compreensão leitora também são os que melhor se autoavaliaram. Os dados são discutidos considerando as implicações psicoeducacionais concernentes à modalidade de ensino investigada.

Palavras-chave: ensino fundamental; teste de Cloze; desempenho escolar; compreensão leitora

\section{Comprensión de la Lectura y Rendimiento Escolar Autopercibido en la Enseñanza Primaria}

\begin{abstract}
Resumen
Este artículo tuvo como objetivo investigar la comprensión de la lectura y posibles asociaciones con el rendimiento escolar autopercibido en alumnos de Enseñanza Primaria. Participaron 298 estudiantes matriculados desde $2^{\circ}$ al $9^{\circ}$ año en escuelas públicas de los Estados de San Pablo y Paraná. Se aplicaron, colectivamente, dos tests de Cloze: uno específico para la primera etapa de Enseñanza Primaria y otro para la segunda. Los resultados demostraron que los alumnos presentaron comprensión en la lectura considerada instructiva. También se observaron diferencias estadísticamente significativas entre puntuación en el Cloze y autopercepción del rendimiento escolar. En general, se puede decir que los estudiantes que presentaron mejor nivel de comprensión de lectura también fueron los que mejor se autoevaluaron. Los datos son discutidos considerando las implicaciones psicoeducativas concernientes a la modalidad de enseñanza investigada.

Palabras-clave: Enseñanza Primaria; test de Cloze; rendimiento escolar; comprensión de lectura
\end{abstract}

Reading and comprehension is one of the most complex cognitive activities performed by humans. It requires the use of several combined cognitive skills that demand interaction between the reader and the text (Monteiro \& Santos, 2013; Mota, 2015). It includes elements such as vocabulary knowledge, linguistic and semantics decoding, inferring, analysis, synthesis, creativity, and also relating the content with other knowledges previously acquired (Oliveira, Lúcio \& Miguel, 2016a; Oliveira, Santos, Boruchovitch \& Rueda, 2012a). According to Corso, Piccolo, Miná \& Salles (2015), reading comprehension is not established only by internal causes such as the cognitive ability of each subject, but also depends on external causes such as the learning environment and reading practices involved in the process. 
In the school context, reading goes beyond the acquisition of knowledge, it allows the development of the students' critical thinking, enabling them to analyze and question the contents read from their own ideas and personal values (Monteiro \& Santos, 2013; Oliveira et al, 2016a). Vendramini \& Mizobuti (2015) and Oliveira et al. (2016a) state that the elementary school is an essential educational stage and should be researched on reading comprehension, as it is at this level that key strategies can be developed, which are necessary for the formation of the reader student.

Due to its complex nature, which requires the interaction between different cognitive processes, the evaluation of this construct requires instruments that deal with the multiplicity of aspects related to reading and that provide reliable results (Joly \& Piovezan, 2012; Oliveira, Santos \& Rosa, 2016). Among the instruments used to assess reading comprehension in the different school stages, the Cloze test is the most used in these investigations (Mota, 2015).

In the scientific literature, several studies which investigated the reading comprehension have used the Cloze test both for diagnosis and for the intervention of the processes relevant to reading (Joly \& Piovezan 2011, Oliveira, Boruchovitch \& Santos, 2008, Suehiro, 2013). As reported by Oliveira (2011) and Suehiro (2013), the choice of using the Cloze by scholars of this theme is attributed mainly to its flexibility and ease of use and scoring (Mota, 2015; Mota \& Santos, 2014).

The traditional structure of the Cloze test consists of a text, composed of about 250 words, which omits every fifth word, except only for the first and last paragraphs, which remain unchanged. In the gaps obtained there is a dash of size proportional to the suppressed term (Joly, Bonassi, Dias, Piovezan \& Silva, 2014). For Oliveira et al. (2012a) and Mota and Santos (2014), the difficulty of a Cloze item can be determined by intrinsic factors (positive elements that favor the accomplishment of the task and motivate the understanding of the item) and extrinsic ones (refer to strategies used to execution of the task and the knowledge that the reader shows on the subject)

We made a search for researches in the last five years (2011-2016), which used the Cloze test to investigate the reading comprehension of elementary school students. For this, we gathered papers conducted nationwide, available in the databases Scielo, Portal Capes, Instituto Nacional de Estudos e Pesquisas Educacionais Anísio Teixeira - INEP and Google Scholar. We should clarify that for the research and selection of these productions we used descriptors and keywords in line with the theme researched in this study, incase, "cloze test", "cloze technique", "primary education and cloze" and more derivations of the theme.

As for the studies that had elementary school students, we found researches directed at the early years (Borges \& Santos, 2016; Bortolanza \& Cotta, 2012; Carvalho, Monteiro, Alcará \& Santos, 2013; Cunha \& Santos, 2015; Gomes \& Boruchovitch, 2011; Machado \& Capellini, 2016; Monteiro \& Santos, 2013; Mota et al., 2012; Mota \& Santos, 2014; Oliveira, Santos, Boruchovitch \& Rueda, 2012b; Suehiro \& Santos, 2015; Witter \& Silva, 2011), final years (Baptista et al., 2016; Joly \& Piovezan, 2012; Joly et al., 2014; Oliveira et al., 2012a) and in both modalities (Oliveira et al., 2016). It is also noteworthy that among the reported studies, the study of reading comprehension was related to several variables such as gender, school year, type of school, writing skills, metatextual awareness, differential operation by Cloze test items, school performance, among others.

The research by Suehiro and Santos (2015), with the participation of 112 children of the 2 nd and 5 th years, found that students with the highest scores in the assessments relevant to phonological awareness were also those who got the highest scores in reading comprehension tests. The study by Mota et al. (2012), with 42 students from the 2 nd and 3 rd years indicated that, regardless of the initial level of phonological awareness, students who have obtained the best results in morphological decision tasks were also those who showed the highest scores on contextual reading.

The results achieved in the research by Witter and Silva (2011), with 80 students, revealed that both the public school students as those of private, showed low level of reading comprehension, however, in the comparative analysis the students of private schools obtained better results. In the study by Monteiro and Silva (2013), with 404 students, also identified that students from private schools, especially those with higher familial support, showed improved performance on reading comprehension.

In turn, the research developed by Oliveira et al. (2016) with 1,316 students from 2 nd to 9th grade from municipal and state public schools signaled that the students of the state school showed better understand the reading than students in city schools.

It is also worth mentioning the researches carried out by Gomes and Boruchovitch (2011), Joly and Piovezan (2012) and Machado and Capellini (2016), which 
used intervention measures to assess and promote reading comprehension. These studies found similar results, since the authors describe consistent and effective gains among students who received the intervention to aid reading comprehension.

The Cloze test's efficiency to measure and improve reading comprehension was studied by Bortolanza and Cotta (2012), with the participation of 24 students of the 5 th grade that were distributed between two groups, one control and one experimental. The experimental group participated in 12 Cloze tests throughout one month, while the control group only participated in the last session of these tests. The results indicated higher scores on the textual interpretation from the students in the experimental group, showing the Cloze as an effective technique for measuring and improving the performance of the reading comprehension.

To investigate the validity of Cloze test as a measure of reading comprehension, Mota and Santos (2014) conducted comparative analysis between the scores with the Cloze and the Academic Performance Test (Teste de Desempenho Escolar - TDE). 42 students in the 1st and 2nd years of elementary school answered two cloze texts and two subtests of TDE. The results indicated that the standards of the average Cloze were consistent with the TDE classification and that, in general, the Cloze proved to be a reliable tool to assess the reading comprehension of students who are in the early years of elementary school.

The investigations that supported the study by Borges and Santos (2016) correlated reading comprehension, school performance and childhood depression. The study had the participation of 293 students from the early years of elementary school and the achieved indexes showed that students who had higher test scores for depressive symptoms showed the weakest performance to understand the assigned reading.

The Cloze test was one of the instruments used by Baptista et al. (2016) that evaluated the relationship between reading comprehension and reading practices of 121 students from the 6th and 7th grade. According to the results achieved, students that showed preference for pleasurable reading (comic books, manga and others) also underperformed in reading comprehension, while students who read school related content had better scores in interpreting texts. These results led the researchers to consider a valid hypothesis to understand this scenario, which is the possibility that students who had low results in textual interpretation would be replacing the study of school subjects with reading comic books, manga and etc.

On the subject of school performance, Tonelotto et al. (2005) and Conceição (2014), report that from the start of the schooling process, the student gets special attention from parents and teachers on their school performance, especially regarding the appropriation of reading skills, logical-mathematical reasoning and writing. In this perspective, Tonelotto et al. (2005) point out that $\mathrm{a}$ an adequate school/academic performance is one in which the student performs, effectively, the school tasks required to achieve learning.

However, Oliveira, Boruchovitch and Santos (2008) explain that to analyze school performance it is necessary to note that different factors may have implications on the performance presented by the student, for example, factors related to school, the family and the student himself. According to Oliveira et al. (2008) and Conceição (2014), students who do not achieve a good performance can be faced with conflicting environments at school and in the family. Borges and Santos (2016) also point to this direction, indicating that the student which does not show a good performance in school can express feelings of guilt, shame and worthlessness and even develop a possible framework with symptoms of depression.

For Godoy, Abrahão and Halpera (2013), the feelings developed by the student are related to the student's self-perception about their intellectual potential and their ability to get a good school performance. According to the authors, it is the perception that students have of themselves and their abilities and difficulties, whether motor, social, cognitive and/or affective. Godoy et al. (2013) also point out that the student who does not have a good school performance tends to strengthen feelings of inadequacy, contributing to the continuously low outcomes and increasing the chances of losses in social relations and their motivation to learn.

Additionally to the survey to identify the publications on researches that made use of the Cloze test, this study also searched for national productions, considering the period between 2011-2016, which set out to investigate the perception of students of elementary school on their school/academic performance.

We designated keywords and description words representing the subject investigated in this study, namely: "perceived school performance", "perception of school performance," "self-perception of school/academic performance," "self-perceived school 
performance" and other derivatives which expressed the subject studied. It should be clarified that we only selected studies that investigated the said subject with the participation of elementary school students (Ferreira et al., 2011; Lira \& Enricone, 2011; Zunino et al., 2012; Godoy et al., 2013; Osti \& Brenelli, 2013; Moreira, Martins-Reis \& Santos, 2016).

The study by Zunino et al. (2012), had 158 students enrolled in the 4th grade (currently 5th year), and indicated that students who find support in friendships think of themselves as well accepted socially and competent about their academic and athletic performance. The results achieved in the survey conducted by Osti and Brenelli (2013), developed with 20 students attending the 5 th year showed that students have low expectations about their school performance and believe that their teachers also have a negative perception of their skills and competences.

Lira and Enricone (2011) investigated 18 students enrolled in 5th grade (currently 6th year) of elementary school and found that a significant number of students has no awareness of their own performance given the contrast of the results obtained, considering the estimated actual results and the performance perceived by the students. The research conducted by Godoy et al. (2013), with 1,070 school students, found that negative self-perception can act as a determining factor in school performance.

The indices obtained in the study by Moreira et al. (2016), with 65 students from 4th to 7th years, indicated that students have a less negative perception than that of their parents about their school performance. The authors stressed the need to work on the self-perception of students from the early years of elementary school, as this perception can significantly contribute to the improvement in academic performance.

In this regard, Ferreira et al. (2011) and Rufini, Bzuneck and Oliveira (2012) also emphasize that students with positive self-perception show confidence in their intellectual potential and, consequently, their competence to learn the content and reach school/academic success. For success in learning, especially in elementary school students, Oliveira et al. (2008) point out that academic performance is directly related to reading comprehension, since reading mediates the acquisition and dominion of school content arising from various fields of knowledge. Given the above, this study aimed to investigate the reading comprehension and possible associations with self-perceived school performance in elementary school students.

\section{Method}

\section{Participants}

298 students enrolled in four public schools in the states of São Paulo (66.4\%, $\mathrm{n}=198)$ and Paraná $(33.6 \%$, $\mathrm{n}=100)$. The average age was 11.7 years $(\mathrm{SD}=2.0)$, the minimum age was 8 years and the maximum 16. The girls represented $51.3 \%$ of the sample $(n=153)$ and boys $48.7 \%(n=145)$. The distribution of students by school year can be seen in Table 1 .

Table 1

\begin{tabular}{ccc}
\multicolumn{3}{c}{ Students distribution by school year } \\
\hline School Year & $F$ & $\%$ \\
\hline $2^{\text {st }}$ & 31 & 10.4 \\
$3^{\text {td }}$ & 37 & 12.4 \\
$4^{\text {th }}$ & 32 & 10.7 \\
$5^{\text {th }}$ & 51 & 17.1 \\
$6^{\text {th }}$ & 58 & 19.5 \\
$7^{\text {th }}$ & 38 & 12.8 \\
$8^{\text {th }}$ & 30 & 10.1 \\
$9^{\text {th }}$ & 21 & 7.0 \\
Total $^{\text {Th }}$ & 298 & 100.0 \\
\hline
\end{tabular}

\section{Instruments}

We asked students to complete a questionnaire with the data required for identification (age, sex and school year). After the fields for identifying data, the instrument provided instructions for reading the text and to fill the gaps with the word that the student considered appropriate to accomplish reading comprehension.

Further, the instrument brings the text entitled 'The Princess and the ghost' to effect the Cloze test. The text was created specifically to investigate the reading comprehension of elementary students (2nd to 5th years). The text contained approximately 103 words and 15 gaps. In the case of middle school students (6th to 9th years) we used the text 'Things of Nature', with approximately 236 words and 40 omissions, both texts written by Santos (2005).

Students should fill the gaps with words they deem appropriate to make sense of the text, with the same having been prepared in accordance with the Cloze technique in its traditional version, omitting every fifth word. In place there was a dash of size proportional 
to the word deleted. It was also asked that students indicate a score of 1-5 on their perceived school performance during the year. The alternatives were very bad (1), Bad (2) Average (3) Good (4) and Very good (5).

\section{Procedures}

This study was in accordance with Resolution No. 466/12 and the complements by the National Health Council (Conselho Nacional de Saúde) - CNS. It is worth noting that this study was part of a survey investigating variables related to school performance in elementary school. The project was approved by the Research Ethics Committee of the university to which it was bound, according to the Protocol 1.751.008/2016, it was considered appropriate and including all required standards and requirements for conducting research.

The legal guardians were also informed and confirmed the permission for student participation by signing the Informed Consent Form - ICF and students were informed about the study objectives and agreed to participate. The explanations presented to the students followed the guidelines and requirements set by Resolution 466/2012 of the CNS.

The application of the instrument happened collectively, in class, on day and time scheduled by the institutions and had an approximate duration of 30 minutes. It is worth mentioning that in the case of the 2 nd year students, the collection was held on the last two school months so that they could respond to the instrument.

\section{Data analysis}

The data were organized in a spreadsheet and using the software Statistical Packeage for the Social Sciences - SPSS, version 22.0, submitted to descriptive statistics to characterize the sample and average scores on the instruments. We then performed inferential statistics using analysis of variance (ANOVA) in order to investigate possible differences in reading comprehension and perception of school performance. And finally we used the Tukey post hoc test to assess the differences between the averages obtained in the analysis of variance.

We should further clarify that regarding the interpretation of the scores we used the Bormuth (1968) criteria, which highlights three levels of reading comprehension. In the first level, frustration, the reader can not exceed 44\% accuracy, therefore with no understanding of the read information. On the second level, instructional, those between $44.1 \%$ and $57 \%$ correct answers, are considered to have literal understanding, which is just enough to understand the meaning of the content. The final level is the independent reader, which exceeds $57 \%$ score, so it is considered that the reader is capable of a critical, creative and autonomous reading.

\section{Results}

Initially, a survey was made on how the participants thought of their own school performance and we also observed their reading comprehension. As students of the elementary and middle schools responded to different Cloze tests, we tried to present the results respecting that difference.

In the group of elementary school one can observe that the average reading comprehension was 7.58 (SD=3.5). The minimum score was 0 and the maximum 15 points. For the middle school grades we found that the average reading comprehension was 24.4 $(\mathrm{SD}=4.8)$. The minimum score was 0 and the maximum 33 points. Table 2 shows the results related to the perception of school performance of students of the elementary and middle schools.

To check for possible differences in the Cloze test scores, considering the perception of school performance we appealed to ANOVA. It should be clarified that one of the postulates to use this analysis is that there is homogeneity of variance among the groups (homoscedasticity). Treatment with ANOVA showed that the score on the Cloze test is differentiated by the self-perception of school performance of students both in elementary school $[\mathrm{F}(3,145)=42.000 ; p=$ $0.001]$, and middle school $[F(3,143)=3.805 ; p=0.012]$.

In the case of elementary school, the post-hoc Tukey test showed that the difference in Cloze score was among the students who self-assessed as Very Bad $(\mathrm{M}=2.7)$ and Average $(\mathrm{M}=7.8)(\mathrm{p}=0.001)$, and Very Bad and Good $(\mathrm{M}=9.6)(\mathrm{p}=0.001)$ and Very bad and Very $\operatorname{good}(M=9.3)(p=0.001)$. There was also a difference between those self-perceived as with Bad performance $(\mathrm{M}=3.8)$ and Average $(\mathrm{M}=7.8) \quad(\mathrm{p}=0.001), \mathrm{Bad}$ and Good $(M=9.6)(p=0.001)$ and Bad and Very Good $(M=9.3)(p=0.001)$. Figure 1 shows the data of the elementary school students.

The post-hoc Tukey test showed that the difference in Cloze score was among the students who self-assessed as $\mathrm{Bad}(\mathrm{M}=17.6)$ and Average $(\mathrm{M}=24.3)$ $(\mathrm{p}=0.013)$, Bad and Good $(\mathrm{F}=24.3)(\mathrm{p}=0.005)$ and $\mathrm{Bad}$ and Very good $(F=24.9)(p=0.045)$. Figure 2 shows the data of the middle school students. 
Table 2

Frequency and percentage of self-perception of school performance of early and middle school students

\begin{tabular}{|c|c|c|c|}
\hline \multicolumn{2}{|c|}{ Self-perception of school performance } & $F$ & $\%$ \\
\hline \multirow{8}{*}{ Elementary } & Very bad & 14 & 9.3 \\
\hline & $\mathrm{Bad}$ & 30 & 19.9 \\
\hline & Average & 16 & 10.6 \\
\hline & Good & 42 & 27.8 \\
\hline & Very good & 48 & 31.8 \\
\hline & Total & 150 & 99.3 \\
\hline & No response & 1 & 0.7 \\
\hline & Total & 151 & 100.0 \\
\hline \multirow{5}{*}{ Middle } & Very bad & 5 & 3.4 \\
\hline & $\mathrm{Bad}$ & 52 & 35.4 \\
\hline & Average & 79 & 53.7 \\
\hline & Good & 11 & 7.5 \\
\hline & Total & 147 & 100.0 \\
\hline
\end{tabular}

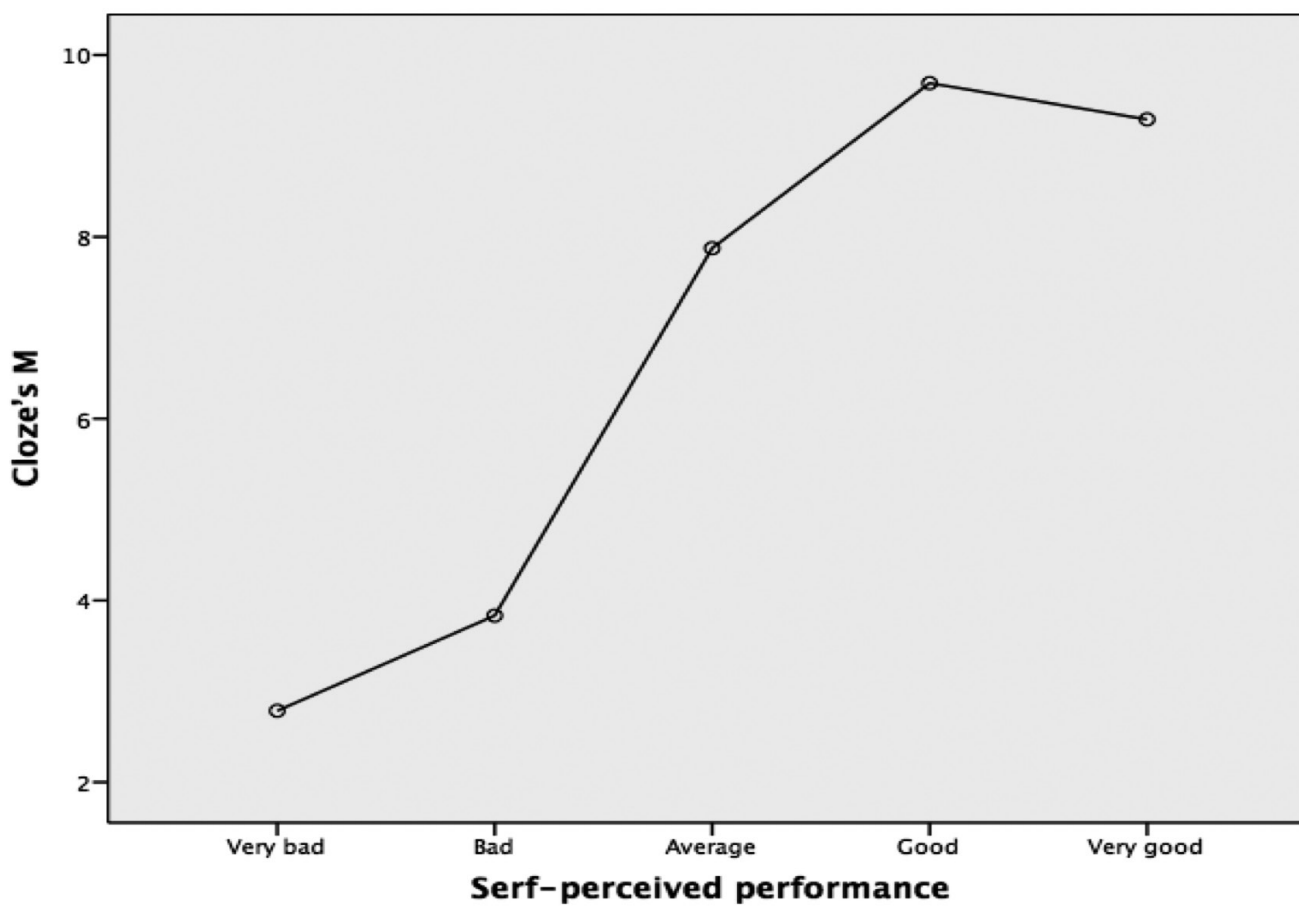

Figure 1. Data of elementary school students

\section{Discussion}

The study investigated the possible relationship between reading comprehension and self-perceived school performance in elementary school students (2nd to 9th grades). Therefore, we applied a test that measured the student's perception about their school performance and two separate Cloze tests to assess 


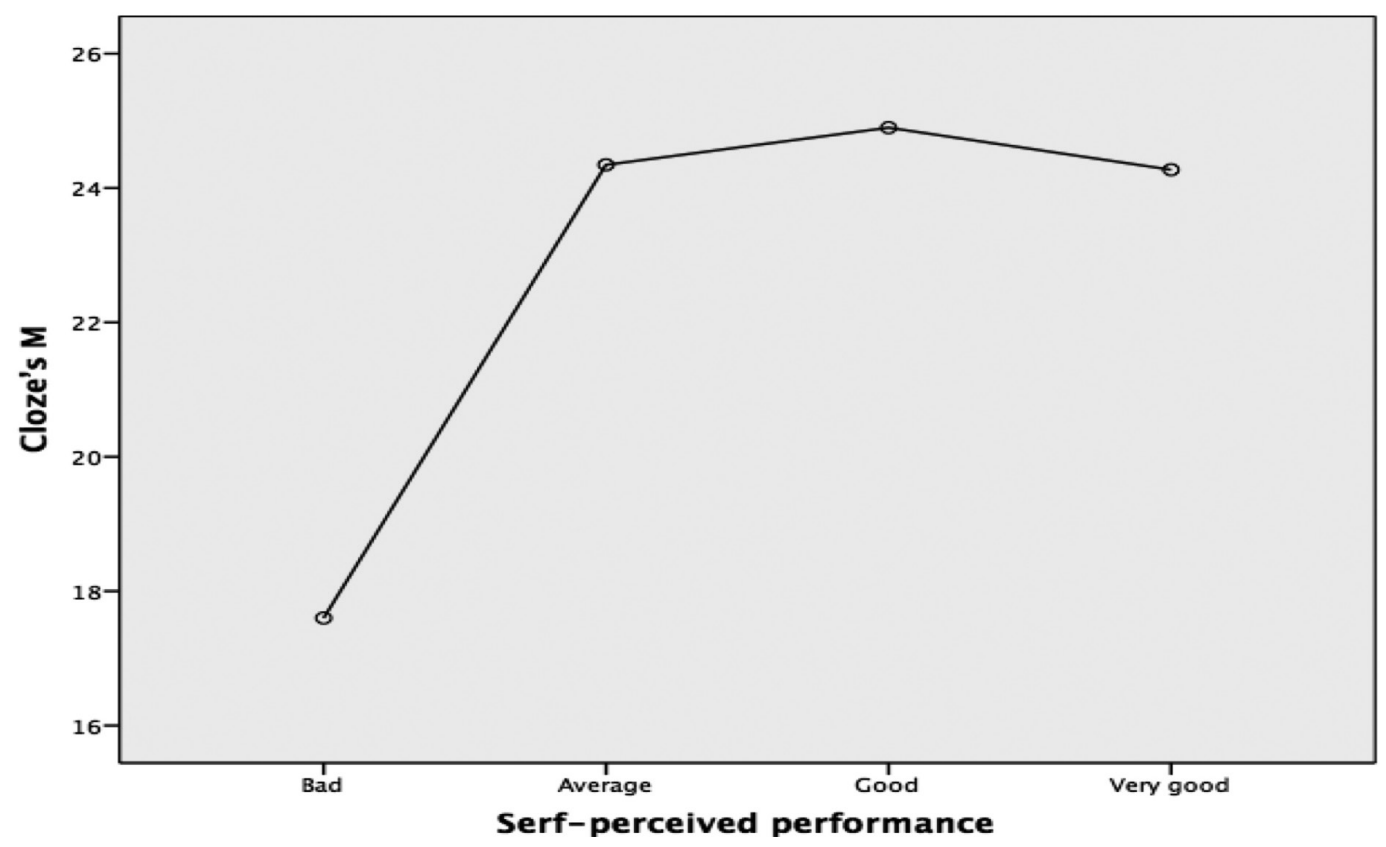

Figure 2. Data of middle school students

reading comprehension. We justify different Cloze tests due to the fact that students were grouped according to the level of education they were at, ie the elementary school group represented the students from the elementary years (2nd to 5 th years) and the final years were in the middle school group (6th to 9th years).

The results showed that most of the sample in both groups had a positive perception of performance, as found in the study by Oliveira, Boruchovitch and Santos (2007) with elementary school students. However, the indices also showed that a considerable portion of the elementary students show a self awareness about their poor or very poor school performance and many middle school students saw their student performance as average. On the other hand, none of the middle school students assessed their school performance as Very bad.

It is worth clarifying that the data analysis comes from a exploratory research and therefore require additional studies to further the investigation. However, we consider the results relevant, since they express the perception that the student has on their skills and abilities and, as pointed out by Oliveira et al. (2008), Rufini et al. (2012) Godoy et al. (2013), the negative perception showed in these results has significant implications for the student's self-esteem, behavior and motivation to learn, factors that directly compromise their school performance.
On reading comprehension, students of elementary school obtained $52 \%$ accuracy, that is, showed a value that according to the classification adopted by Bormuth (1968) corresponds to their instructional level. From this classification it can be inferred that students demonstrate a literal reading comprehension in which the restricted level of abstraction provides only superficial understanding of the meanings and ideas in the text.

Similar indices were obtained in studies by Oliveira et al. (2008) and Oliveira et al. (2012b) in which the authors point out that students with an insufficient reading comprehension level may have difficulty in understanding the information, learning new knowledge and, consequently, in the school performance. The authors also state that students with this level of reading comprehension, commonly require intervention measures from their teachers to fully appropriate what is read.

The middle school students reached $73.9 \%$ accuracy, which is a value that put this group in a reading comprehension level called independent. These results revealed that most of the students of this sample are considered by Bormuth (1968) as proficient readers, able to appropriate the text content making critical and creative inferences. Joly et al. (2014) found results adverse to these, in which students from the final years of elementary school, both from public and private 
schools, were classified at the level of frustration, suggesting that students of that study did not reach the expected level for their educational stage, as they presented restricted understanding of their readings.

On the results obtained in our study, concerning the reading comprehension of middle school students, we should bring the considerations of Piovezan and Castro (2008) and Oliveira et al. (2016), that explicit that it is expected that the level of reading understanding increases systematically as the student advances the years of schooling. However, it is relevant to also assess that the investigation did not include reading comprehension and perceived performance by the student, taking into account the specific school year in which the participants of the sample were enrolled. We estimate that these data could amplify the existing information and provide opportunities to do a more precise analysis of the results. Therefore, we suggest that further researches, investigating the subject researched in this study, contemplate variables such as age, sex, and the distinction of the school year attended by the student.

Regarding the relationship between reading comprehension and academic performance, the results from the two groups indicated that students who self-assessed with a Good or Very good performance are those that also have shown greater ability to read. The elementary students who self-assessed with a Good performance achieved an average $64 \%$ score and were assigned to the independent level of reading comprehension. In contrast, students who judged their performance as Very bad had low reading comprehension, resulting in an approximate index of $18 \%$ correct answers.

The group in middle school had a correlated situation to those in the early e elementary school, who assessed their performance as Very good, given that an index with approximately $75.4 \%$ of correct answers indicated that these students performed a proficient reading of the text. On the other hand, students who perceived themselves as poor performers showed an insufficient understanding of the information presented in the text, with an instructional level of reading comprehension, which was classified from the average result of $53.3 \%$ of correct answers.

Although the research by Oliveira et al. (2008) did not specifically focus on the students' self-perception of their school performance, but on their effective performance, it is observed that the authors obtained results similar to those presented. It should be added that these indices corroborate the considerations of Ferreira et al. (2011) and Godoy et al. (2013). These authors emphasized in their studies the importance of promoting actions that seek to give the student the opportunity to develop an understanding in reading proficiency that allows the appropriation of new knowledge and feed positive experiences to the student's judgment about their ability to learn.

Reading comprehension proficiency is one of the main pillars for learning new knowledge. Given this scenario, this study sought to identify the reading comprehension levels of elementary students associated to the perception that these students present about their school performance. From the results, it was possible to verify that a considerable number of students from the early years of elementary school, who participated in this sample, had reading skills still insufficient for a full understanding of the meaning and idea of the text. Students in the final years of elementary school have demonstrated that they perform an autonomous reading with a critical and creative understanding of the information read.

As indicated by the scientific literature presented in this study, these results are predictable, since there is a progression of reading comprehension as the student progresses in the school years. However, it should also be noted that among the limitations of this study is the fact that the reading comprehension was not analyzed according to the punctual discrimination of the school years attended by the students. In this way, we suggest that future studies add this discrimination between the school years in search of an evaluation that allows a more in-depth understanding of the presented picture.

Regarding the student's perceived scholastic performance, the indices revealed that an expressive portion of the students attributesconcepts between Very bad and Average concepts to their ability to understand the contents and perform school tasks. Given the importance of the student's belief in their ability to successfully perform school activities, these results are significant because they indicate the need for interventional measures, both governmental and psychopedagogical, that strengthen the student's positive perceptions of themselves and of their capabilities. Regarding these results, it is also pertinent to point out that due to the inherent limitations of the exploratory research used in this study, further investigations are recommended that amplify the information collected and allow a more precise examination of the results achieved.

In general, it is considered that this research contemplated the objectives initially proposed and added 
relevant results to the investigated constructs: reading comprehension and perceived scholastic performance. However, it is recommended that future researches consider investigating this, taking into account the school year attended, gender, age and other characteristics of the participants, as well as associating these constructs with factors such as: learning strategies, motivation to learn, family environment, teaching strategies employed by teachers, anxiety, attention, social skills, among others.

\section{References}

Baptista, RM, Freitas Junior, PVD, Peçanha, AP, Soares, AB, \& Mettrau, MB (2016). Práticas de leitura e compreensão de texto no $6^{\circ}$ e $7^{\circ}$ anos do ensino fundamental.Estudos de Psicologia (Campinas),33(1), 173-182, doi: 10.1590/1982-027520160001000017

Borges, L., \& dos Santos, AAA (2016). Sintomatología depresiva y desempeño escolar: un estudio con niños brasileños. Ciencias Psicológicas, 10(2), 189-197. Retrieved from: http://www. scielo.edu.uy/scielo.php?script $=$ sci_arttext\&pi$\mathrm{d}=$ S1688-42212016000200008\&lng=es\&tlng=es

Bormuth, JR (1968). Cloze test readability: Criterion reference scores. Journal of educational measurement,5(3), 189-196, doi: 10.1111/j.1745-3984.1968. tb00625.x/full

Bortolanza, AME, \& Cotta, MAC (2013). Emprego da técnica cloze como instrumento para melhorar o desempenho em leitura. Signo, 37(63), 69-89, doi: 10.17058/signo.v37i63.2912

Carvalho, LF, Monteiro M., R., Alcará, AR, \& Santos, AAA (2013). Aplicação da TRI em uma medida de avaliação da compreensão de leitura.Psicologia: Reflexão \& Crítica,26(1), 47-57, doi: 10.1590/ S0102-79722013000100006

Conceição, ADCK (2014). Desempenho escolar e suas relações com a autopercep̧cão de empatia e competência social em adolescentes. Dissertação de mestrado. Universidade Estadual de Londrina. Faculdade de Educação. Campinas, SP, Brasil.

Corso, HV, Piccolo, LR, Miná, CS, \& Salles, JF (2015). Normas de desempenho em compreensão de leitura textual para crianças de $1^{\circ}$ Ano a $6^{a}$ Série. Psico (PUCRS On-line), 46(1), 68-78. Recuperado de http://www.scielo.br/pdf/rsbf/v16n1/03.pdf
Cunha, NB, \& Santos, AAA (2015). Avaliação da consciência metatextual: um instrumento de medida.Revista de Estudios e Investigación en Psicología y Educación, 0(10), 137-141, doi: 10.17979/ reipe.2015.0.10.922

Ferreira, AA, Conte, KDM, \& Marturano, EM (2011). Meninos com queixa escolar: autopercepções, desempenho e comportamento. Estudos de Psicologia (Campinas), 28(4), 443-451, doi: 10.1590/ S0103-166X2011000400005

Gomes, MAM, \& Boruchovitch, E. (2011). Aprendizagem autorregulada da leitura: resultados positivos de uma intervenção psicopedagógica.Psicologia: Teoria e Pesquisa,27(3), 291-299, doi: 10.1590/ S0102-37722011000300004

Godoy, JA, Abrahão, RC, \& Halpern, R. (2013). Autopercepção de dificuldades escolares em alunos do ensino fundamental e médio em município do Rio Grande do Sul. Aletheia, (41), 121-133. Retrieved from: http://www.redalyc.org/ html/1150/115031073010/

Joly, MCRA, Bonassi, J., Dias, AS, Piovezan, NM, \& da Silva, DV (2014). Avaliação da compreensão de leitura pelo Sistema Orientado de Cloze (SOC). Fractal: Revista de Psicologia,26(1), 223-242, doi: 10.1590/S1984-02922014000100016

Joly, MCRA, \& Piovezan, NM (2011). Funcionamento diferencial dos itens do Teste Cloze por Opção. Arquivos Brasileiros de Psicologia,63(2), 58-68. Retrieved from: http://pepsic.bvsalud.org/pdf/arbp/ v63n2/07.pdf

Joly, MCRA, \& Piovezan, NM (2012). Avaliação do programa informatizado de leitura estratégica para estudantes do ensino fundamental 1. Paidéia,22(51), 83-90, doi: 10.1590/S0103-863X2012000100010

Lira, ES, \& Enricone, JRB (2011). Relação entre vínculos escolares e desempenho na aprendizagem: Um estudo com alunos de $5^{a}$ série do ensino fundamental. Perspectiva, 35 (132), 65-80. Retrieved from: http://www.uricer.edu.br/site/pdfs/perspectiva/132_234.pdf

Machado, AC, \& Capellini, SA (2016). Dados preliminares de um programa de intervenção para compreensão leitora por meio da técnica de cloze.Revista Psicopedagogia,33(101), 144-153. Retrieved from: http://pepsic.bvsalud.org/scielo.php?script=sci_ 
arttext\&pid=S0103-84862016000200004\&lng=pt \&tlng $=$ pt.

Monteiro, RM, \& Santos, AAA (2013). Recursos familiares e desempenho de crianças em compreensão de leitura. Psico, 44(2), 273-279. Retrieved from: http://revistaseletronicas.pucrs.br/ojs/index. $\mathrm{php} /$ revistapsico/article/view/11758/9646

Moreira, BBG, Martins-Reis, VO, \& Santos, JN (2016). Autopercepção das dificuldades de aprendizagem de estudantes do ensino fundamental. Audiology - Communication Research, 21, e1632, doi: 10.1590/2317-6431-2015-1632

Mota, MMPED (2015). Um olhar crítico sobre os testes de compreensão de leitura.Avaliação Psicológica,14(3), 347-351. Retrieved from: http:// pepsic.bvsalud.org/scielo.php? script $=$ sci_ arttext\&pid=S1677-04712015000300007\&lng=pt \&tlng $=\mathrm{pt}$

Mota, MMPED, \& Santos, AAAD (2014). O Cloze como instrumento de avaliação de leitura nas séries iniciais. Revista Brasileira de Psicologia Escolar e Educacional, 18(1), 135-142. Retrieved from: http:/ /www. scielo.br/pdf/pee/v18n1/v18n1a14.pdf

Mota, MMPE, Vieira, MDT, Bastos, RR, Dias, J., Paiva, N., Mansur-Lisboa, S., \& Andrade-Silva, R. (2012). Leitura contextual e processamento metalingüístico no português do Brasil: um estudo longitudinal.Psicologia: Reflexão e Crítica,25(1), 114120, doi: 10.1590/S0102-79722012000100014

Oliveira, KL (2011). Considerações acerca da compreensão em leitura no ensino superior.Psicologia: Ciência e Profissão,31(4), 690-701, doi: 10.1590/ S1414-98932011000400003

Oliveira, KL, Boruchovitch, E., \& Santos, AAA (2007). Compreensão de leitura em alunos de sétima e oitava séries do ensino fundamental. Psicologia Escolar e Educacional, 11(1), 41-49. Retrieved from: http:// www.scielo.br/pdf/pee/v11n1/v11n1a05.pdf

Oliveira, KL, Boruchovitch, E., \& Santos, AAA (2008). Leitura e desempenho escolar em português e matemática no ensino fundamental. Paidéia (Ribeirão Preto), 18(41), 531-540, doi: 10.1590/ S0103-863X2008000300009.

Oliveira, KL, Lúcio, PS, \& Miguel, FK (2016a). Considerações sobre habilidade de compreensão em leitura e formas de sua avaliação.
Psicologia Escolar e Educacional, 20(1), 69-77, doi: 10.1590/2175-353920150201930

Oliveira, KL, Santos, AAA, Boruchovitch, E., \& Rueda, FJM (2012a). Compreensão da leitura: análise do funcionamento diferencial dos itens de um Teste de Cloze. Psicologia: Reflexão e Crítica,25(2), 221-229, doi: 10.1590/S0102-79722012000200003

Oliveira, KL, Santos, AAA, Boruchovitch, E., \& Rueda, FJM (2012b). El test de Cloze en la enseñanza primaria: funcionamiento diferencial del ítem. $L i$ berabit, 18(1), 45-52. Retrieved from: http://www. scielo.org.pe/pdf/liber/v18n1/a06v18n1.pdf

Oliveira, KL, Santos, AAAD, \& Rosa, MT (2016). Compreensão em Leitura no Ensino Fundamental. Psicologia: Ciência e Profissão,36(3), 546-557, doi: 10.1590/1982-3703001172014

Osti, A., \& Brenelli, RP (2013). Sentimentos de quem fracassa na escola: análise das representações de alunos com dificuldades de aprendizagem. Psico-USF, 18(3), 417-426, doi: 10.1590/S1413-82712013000300008

Piovezan, NM, \& Castro, NR (2008). Compreensão e estratégias de leitura no ensino fundamental. PSIC: Revista de Psicologia da Vetor Editora, 9(1), 53-62. Retrieved from: http://pepsic.bvsalud.org/pdf/ psic/v9n1/v9n1a07.pdf

Rufini, SE, Bzuneck, JA, \& Oliveira, KL (2012). A qualidade da motivação em estudantes do ensino fundamental. Paidéia, 22(51), 53-62. Retrieved from: http://www.scielo.br/pdf/paideia/v22n51/07. pdf

Santos, AAA (2005). O Teste de Cloze como instrumento de diagnóstico e de desenvolvimento da compreensão em leitura. Itatiba, SP: Universidade São Francisco. Relatório de pesquisa não-publicado.

Suehiro, ACB (2013). Produção científica sobre o Teste de Cloze.Revista Brasileira de Psicologia Escolar e Educacional, 17(2), 223-232, doi: 10.1590/ S1413-85572013000200004

Suehiro, ACB, \& Santos, AAAD (2015). Compreensão de leitura e consciência fonológica: evidências de validade de suas medidas. Estudos de Psicologia (Campinas), 32(2), 201-211, doi: 10.1590/0103-166X2015000200005

Tonelotto, JMDF, Fonseca, LC, Tedrus, GM, Martins, SMV, Gibert, MAP, Antunes, TDA, \& Pensa, NAS 
(2005). Avaliação do desempenho escolar e habilidades básicas de leitura em escolares do ensino fundamental. Avaliação Psicológica, 4(1), 33-43. Retrieved from: http://pepsic.bvsalud.org/pdf/avp/ v4n1/v4n1a05.pdf

Vendramini, C., \& Mizobuti, R. (2015). Relação entre compreensão em leitura e letramento estatístico. Educare, Revista Cientifica de Educação, 1(1), 133-152. Retrieved from: https://revistas.unasp.edu.br/ lumen/article/viewFile/582/pdf

Witter, GP, \& Silva, EMT (2011). Leitura e escrita: tipo de escola, gênero e série. Boletim Academia Paulista de
Psicologia, 31(4), 119-123. Retrieved from: http:// www.redalyc.org/html/946/94622764012/

Zunino, LMR, Manfroib, EC, Nunesc, SAN, Faracoa, AMX, Vieira, ML, \& Rubind, KH (2012). Correlações entre Dimensões da Qualidade das Amizades e Autopercepção em Crianças. Interação em Psicologia, 16(2), 137-147, doi: 10.5380/psi.v16i2.23061

Recebido em: 13-10-2017

Reformulado em: 06-03-2018

Aprovado em: 29-03-2018

Contato com as autoras:

Andrea Carvalho Beluce é Pedagoga com especialização em Metodologia da Ação Docente pela Universidade Estadual de Londrina (UEL) e Especialização em Mídias Integradas (UFPR). Mestre e Doutoranda pelo Programa de Pós-graduação em Educação da UEL. Gestora Pedagógica do Ambiente Virtual de Aprendizagem da Prefeitura Municipal de Londrina e diretora da Escola de Governo da PML - formação dos servidores municipais.

E-mail: andreabeluce@gmail.com

Amanda Lays Monteiro Inácio é Psicóloga com habilitação em Bacharelado e Formação de Psicólogo pela Universidade Estadual de Londrina - UEL. Especialista em Clínica Psicanalítia pela UEL, Mestre em Educação pelo Programa de Mestrado e Doutorado da UEL e Doutoranda pela Universidade de São Francisco. Experiência na área de Psicologia com ênfase em Avaliação Psicológica e Avaliação Psicoeducacional e Psicologia e Psicanálise.

E-mail: amandalmonteiroo@gmail.com

Katya Luciane de Oliveira é Psicóloga. Mestre em Psicologia pelo Programa de Estudos de Pós-graduação Stricto Sensu em Psicologia da Universidade de São Francisco. Doutora em Psicologia, Desenvolvimento Humano e Educação pela Faculdade de Educação da Unicamp. Docente do curso de Psicologia/PPSIC e do Programa de Pós-graduação Stricto Sensu em Educação da UEL. Bolsista Produtividade Nível 2/CNPq.

E-mail:katyauel@gmail.com

Sandra Aparecida Pires Franco é Pedagoga. Mestre em Educação pelo Programa de Pós-Graduação Stricto Sensu em Educação da Universidade Estadual de Maringá, Doutora em Letras pelo Programa de Pós-Graduação em Estudos Literários da UEL. Docente do Curso de Pedagogia e do programa de Pós-graduação da UEL.

E-mail: sandrafranco26@hotmail.com

Contato com as autoras:

Universidade Estadual de Londrina, Centro de Ciências Biológicas, Depto de Psicologia e Psicanálise

Rodovia Celso Garcia Cid, Pr 445 Km 380, Campus Universitário

Londrina-PR, Brasil

Caixa Postal 6001

CEP: 86051-980

Psico-USF, Bragança Paulista, v. 23, n. 4, p. 597-607, out./ dez: 2018 